\title{
microRNA-18b is upregulated in breast cancer and modulates genes involved in cell migration
}

\author{
MIGUEL A. FONSECA-SANCHÉZ ${ }^{1}$, CARLOS PÉREZ-PLASENCIA ${ }^{2,3}$, JORGE FERNÁNDEZ-RETANA ${ }^{2}$, \\ ELENA ARECHAGA-OCAMPO ${ }^{4}$, LAURENCE A. MARCHAT ${ }^{5}$, SERGIO RODRÍGUEZ-CUEVAS ${ }^{6}$, \\ VERONICA BAUTISTA-PIÑA ${ }^{6}$, ZAIRA E. ARELLANO-ANAYA ${ }^{1}$, ALI FLORES-PÉREZ ${ }^{1}$, \\ JOSÉ DIAZ-CHÁVEZ ${ }^{7}$ and CÉSAR LÓPEZ-CAMARILLO ${ }^{1}$
}

\begin{abstract}
${ }^{1}$ Oncogenomics and Cancer Proteomics Laboratory, Genomics Sciences Program, Autonomous University of Mexico City, Mexico City; ${ }^{2}$ Oncogenomics Laboratory, National Institute of Cancerology, Mexico City; ${ }^{3}$ Biomedicine Unit, Superior Studies Faculty-Iztacala, National University of Mexico, Mexico City; ${ }^{4}$ Virus and Cancer Laboratory, National Institute of Cancerology, Mexico City; ${ }^{5}$ Molecular Biomedicine Program and Biotechnology Network, National School of Medicine and Homeopathy, National Polytechnic Institute, Mexico City;

${ }^{6}$ Institute of Breast Diseases-FUCAM, Mexico City; ${ }^{7}$ Unit of Biomedical Research in Cancer, Institute of Biomedical Research, UNAM/National Cancer Institute, Mexico City, Mexico
\end{abstract}

Received June 28, 2013; Accepted August 2, 2013

DOI: $10.3892 /$ or.2013.2691

\begin{abstract}
RNAs are small non-coding RNAs of $\sim 22$ nucleotides that function at post-transcriptional level as negative regulators of gene expression. Aberrant expression of microRNAs could promote uncontrolled proliferation, migration and invasion of human cancer cells. In this study, we analyzed the expression of microRNA-18b (miR-18b) in breast cancer cell lines and in a set of clinical specimens. Our results showed that miR-18b was upregulated in four out of five breast cancer cell lines and also in breast tumors. In order to identify potential gene targets, we carried out transcriptional profiling of MDA-MB-231 breast cancer cells that ectopically expressed miR-18b. Our results showed that 263 genes were significantly modulated in miR-18b-deficient cells (fold change $>1.5 ; \mathrm{P} \leq 0.05$ ). We found that knock-down of miR-18b induced the upregulation of 55 olfactory receptor (OR) genes and nine genes (NLRP7, KLK3, OLFM3, POSTN, MAGED4B, KIR3DL3, CRX, SEMG1 and CEACAM5) with key roles in cell migration and metastasis. Consistently, we found that ectopic inhibition of miR-18b suppressed the migration of two breast cancer cell models in vitro. In conclusion, we have uncovered genes directly or indirectly modulated by
\end{abstract}

Correspondence to: Dr César López-Camarillo, Oncogenomics and Cancer Proteomics Laboratory, Genomics Sciences Program, Autonomous University of Mexico City, San Lorenzo 290, Col del Valle, 03100 Mexico City, Mexico

E-mail: genomicas@yahoo.com.mx

Key words: breast cancer, tumor marker, microRNA-18b, expression profiling, transcriptome, cell migration
miR-18b which may represent potential therapeutic targets in breast cancer. Our data also pointed out a role of miR-18b in migration of breast cancer cells.

\section{Introduction}

microRNAs are small non-coding RNAs of $\sim 22$ nucleotides that function at post-transcriptional level as negative regulators of gene expression. In normal cells, microRNAs maintain a balance of key cellular processes including cell growth, proliferation, differentiation and cell death. Abnormal expression of microRNAs occurs frequently in breast cancer where they act as oncogenes and tumor-suppressors. microRNAs may contribute to tumor initiation and progression by inhibiting apoptosis and promoting uncontrolled proliferation, invasion and metastasis. In consequence, they represent potential prognostic markers and novel therapeutic targets in human cancer (1). In animal cells, microRNAs are frequently transcribed together as polycistronic primary transcripts that are processed into multiple individual mature microRNAs. Particularly, microRNA-18b (miR-18b) is located at chromosome $\mathrm{X}$ within the miR-106a-363 cluster that is constituted by six different microRNAs $(2,3)$. It has been proposed that expression of this microRNAs cluster is undetectable or very low in mouse (4). Diverse reports associated the aberrant expression of miR-18b to diverse human pathologies including cardiac hypertrophy (5), multiple sclerosis (6) and hepatitis B virus chronic infection (7). In human cancer, miR-18b expression is also deregulated. It has been reported that miR-18b is highly expressed in gastric cancer (8), in malignant serous tumors from borderline and benign ovarian tumors (9), in basal cell carcinoma of the skin (10), and in colonic cancer (11). Some miR-18b targets have been experimentally identified. In stem-like cells isolated from glioblastoma, it was reported that miR-18b targets the NOTCH2, NEDD9 and 
MEKK1 genes (12). In breast cancer miR-18a, miR-18b, and other 21 microRNAs negatively regulate the estrogen receptor (ER)- $\alpha$ signaling (13). In addition, miR-18a and miR-18b showed higher expression levels in ER- $\alpha$ negative clinical specimens (13). In another study, a low expression of miR-18b was associated with improved survival in human epidermal receptor (HER) 2-negative breast cancer, although it was not correlated with ER- $\alpha$ protein levels (14). Recently, higher levels of circulating miR-18b were proposed as a potential marker of breast cancer (15). Although knowledge on the roles of miR-18b in cancer is increasing, the physiological functions still remain unclear and the number of detected miR-18b targets in cancer is scarce. Here, we studied the miR-18b expression in breast cancer cell lines and clinical tumors. In addition, we performed a genomic-wide study using DNA microarrays in order to identify genes regulated by miR-18b with putative roles in breast cancer.

\section{Materials and methods}

Tissue samples. Human primary breast tumors and adjacent non-tumoral tissues were obtained from the Institute of Breast Diseases-FUCAM, Mexico. Biopsies were obtained from breast cancer patient after selection following the regulations approved by the FUCAM Ethics Committee, including patient informed consent for research use. None of the patients recruited in this study received anti-neoplastic therapy prior to surgery. After tumor resection, specimens were embedded in Tissue-Tek and snap-frozen in liquid nitrogen at $-80^{\circ} \mathrm{C}$ until analysis. A pathologist analyzed samples for the amount of tumoral cells and to validate non-tumoral tissues. Tumor tissues containing at least $80 \%$ of tumor cells and non-tumoral tissues confirmed by the pathologist were used for subsequent analysis.

Cell line cultures. Human MDA-MB-231, MDA-MB-453, ZR-75, T47-D and MCF-7 breast cancer cell lines were cultured in Dulbecco's modified Eagle's medium (DMEM; Invitrogen, Carlsbad, CA, USA) supplemented with $10 \%$ fetal bovine serum (FBS), $100 \mathrm{U} / \mathrm{ml}$ penicillin and $100 \mathrm{mg} / \mathrm{ml}$ streptomycin. Cultures were maintained in a $5 \% \mathrm{CO}_{2}$ humidified atmosphere at $37^{\circ} \mathrm{C}$.

RNA isolation and qRT-PCR analysis of miR-18b expression. Total RNA of tissues and cell lines was extracted using the TRIzol reagent (Invitrogen) according to the manufacturer's protocol. RNA integrity was assessed using capillary electrophoresis system Agilent 2100 Bioanalyzer with the eukaryotic nano-chip. Only samples with a RIN value of 6 or higher were processed. The expression of miR-18b was performed using microRNA assays (Applied Biosystems, Foster City, CA, USA). Total RNA (100 ng) obtained from clinical specimens and cell lines was reverse transcribed using a looped RT primer specific for miR-18b, $0.15 \mu \mathrm{l}$ of dNTPs $(100 \mathrm{mM}), 1.0 \mu \mathrm{l}$ of reverse transcriptase MultiScribe ${ }^{\mathrm{TM}}(50 \mathrm{U} / \mu \mathrm{l}), 1.5 \mu \mathrm{l}$ of $10 \mathrm{X}$ buffer, $0.19 \mu \mathrm{l}$ of RNase inhibitor $(20 \mathrm{U} / \mu \mathrm{l})$ and $4.16 \mu \mathrm{l}$ of RNasefree water. Then, diluted retrotranscription reaction (1:15) was mixed with $10 \mu 1$ of master mix TaqMan (Universal PCR Master mix, No AmpErase ${ }^{\circledR}$ UNG, 2X), $7.67 \mu$ of RNase-free water, and $1.0 \mu \mathrm{l}$ of probe PCR. PCR reaction was done in a GeneAmp System 9700 (Applied Biosystems) as follows: $95^{\circ} \mathrm{C}$ for $10 \mathrm{~min}$, and $40 \mathrm{cycles}$ at $95^{\circ} \mathrm{C}$ for $15 \mathrm{sec}$ and $60^{\circ} \mathrm{C}$ for $1 \mathrm{~min}$. The expression of miR-18b levels were measured by qRT-PCR using the comparative $\mathrm{Ct}\left(2^{-\Delta \Delta \mathrm{C}}\right)$ method. RNU44 and RNU48 were used as a control for normalization of data.

Transfection of the miR-18b inhibitor. MDA-MB-231 and MCF-7 cells were transfected with miR-18b inhibitor (\#MH10466; Life Technologies) and scrambled at indicated final concentrations using siPORT ${ }^{\mathrm{TM}}$ amine transfection agent (Ambion, Inc., Austin, TX, USA). The miR-18b inhibitor was diluted in $25 \mu \mathrm{l}$ of Opti-MEM ${ }^{\circledR}$ to $50-200 \mathrm{nM}$ concentrations, and individually added to wells containing cultured cells in $450 \mu 1$ of DMEM. Knock-down of miR-18b expression was evaluated by qRT-PCR at $48 \mathrm{~h}$ post-transfection.

DNA microarray analysis. To analyze the effects of miR- $18 \mathrm{~b}$ inhibition on gene expression we compared the gene expression profiles of MDA-MB-231 cells transfected with miR-18b inhibitor and with siPORT amine transfection agent (control) using DNA microarrays. Total RNA $(1 \mu \mathrm{g})$ was employed for cDNA synthesis and labeling using Amino Allyl MessageAmp ${ }^{\text {TM }}$ II aRNA Amplification kit (Ambion) following manufacturer's instructions. Total RNA obtained $48 \mathrm{~h}$ after transfection with empty transfection agent was labeled with $\mathrm{Cy} 3$, whereas cDNA from cells transfected with miR-18b inhibitor was Cy5 labeled. Dye incorporation efficiency was analyzed measuring specific absorbance. Samples (500 pmol) were hybridized onto Human Exonic Evidence Based Oligonucleotide (HEEBO) arrays obtained from the Stanford Functional Genomics Facility (Stanford, CA, USA). Each microarray contained 43,000 spots, including 85.8\% I.M.A.G.E. consortium clones from the Research Genetics sequence verified clone set and 4.4\% control spots, corresponding to 18,141 mapped human genes. Hybridization was performed at $42^{\circ} \mathrm{C}$ for $18 \mathrm{~h}$. Following hybridization, arrays were washed and scanned using a GenePix 4100A Axon scanner (Axon Instruments, Inc., Union City, CA, USA). Fluorescence ratios were extracted using GenePix 5.0 software (Axon Instruments, Inc.). We defined well-measured spots by: i) having a ratio of normalized signal intensity to background noise of $>2$ for either the Cy5 signal derived from miR-18b inhibitor transfected cells, or the Cy3 signal derived from empty transfected cells and, ii) with no flag assignation by GenePix software which corresponds to poor spot quality caused by non-reliable hybridization and corruption by noise. We performed an algorithm on Microsoft Excel to accomplish both conditions. Background-subtracted fluorescence $\log 2$ ratios were globally normalized for each array, and then mean-centered for each gene. Each microarray experiment was repeated as technical replicates for statistical robustness. Finally, to avoid bias caused by different properties of the two cyanine dyes we balanced the intensity level of both channels using Lowess normalization method included on ArrayNorm software (16).

MTT cell viability assay. To evaluate the cell viability after inhibition of miR-18b in MDA-MB-231 and MCF-7 cells a standard 3-(4,5-dimethylthiazol-2-yl)-2,5-diphenyltetrazolium bromide (MTT) colorimetric assay was performed. Cells $\left(2 \times 10^{4}\right)$ transfected with miR-18b inhibitor $(50 \mathrm{nM})$, scramble 
Table I. Clinicopathological features of breast cancer patients and tumors analyzed for miR-18b expression.

\begin{tabular}{lccccccccc}
\hline $\begin{array}{l}\text { Patient } \\
\text { no. }\end{array}$ & $\begin{array}{c}\text { Age } \\
\text { (years })\end{array}$ & $\begin{array}{c}\text { Tumor size } \\
(\mathrm{mm})\end{array}$ & $\begin{array}{c}\text { Clinical } \\
\text { stage }\end{array}$ & $\begin{array}{c}\text { Tumor } \\
\text { grade }\end{array}$ & HER2 & ER & PR & Classification & Histological subtype \\
\hline 15 & 45 & 35 & ND & 2 & + & - & + & HER2-positive & Infiltrating ductal carcinoma \\
30 & 41 & 20 & 0 & 2 & + & + & + & Luminal B & In situ ductal carcinoma \\
75 & 50 & 25 & IIB & 2 & + & - & - & HER2-positive & Infiltrating ductal carcinoma \\
76 & 49 & 20 & IIB & 3 & + & - & - & HER2-positive & Infiltrating ductal carcinoma \\
78 & 81 & 47 & IIIB & 3 & + & - & - & HER2-positive & Infiltrating ductal carcinoma \\
79 & 56 & 15 & IIA & 2 & + & - & - & Luminal A & Infiltrating ductal carcinoma \\
82 & 59 & 25 & IIB & ND & + & - & - & Luminal A & Infiltrating ductal carcinoma \\
85 & 47 & 27 & IIA & 3 & + & - & + & HER2-positive & Infiltrating ductal carcinoma \\
98 & 65 & 30 & IIA & ND & + & - & - & Luminal A & Infiltrating ductal carcinoma \\
105 & 39 & 23 & IIIC & 2 & + & - & + & HER2-positive & Infiltrating ductal carcinoma \\
139 & 44 & 30 & IIB & 3 & - & - & - & Triple negative & Infiltrating ductal carcinoma \\
169 & 65 & 40 & IIB & ND & - & - & - & Triple negative & Infiltrating medular carcinoma \\
191 & 55 & 39 & IIB & 2 & + & - & - & HER2-positive & Infiltrating ductal carcinoma \\
\hline
\end{tabular}

ER, estrogen receptor; PR, progesterone receptor; HER2, human epidermal receptor 2; ND, not determined.

sequence, and siPORT transfection reagent as controls were seeded in 48-well culture dishes and incubated in MTT $(1 \mathrm{mg} / \mathrm{ml})$ at $37^{\circ} \mathrm{C}$ for $4 \mathrm{~h}$. The medium was removed and formazan dye crystals were solubilized with $500 \mu 1$ isopropanol, $4 \mathrm{mM} \mathrm{HCl}, \mathrm{NP}-400.1 \%$ for $5 \mathrm{~min}$. Absorbance was measured in a spectrophotometer at $540 \mathrm{~nm}$ wavelength. Assays were performed in triplicate.

Cell migration assays. To evaluate the effect of miR-18b inhibition in MDA-MB-231 and MCF-7 cell migration a scratch/wound-healing assay was performed. Briefly, cells transfected with the miR-18b inhibitor (50 nM), scramble sequence, and siPORT transfection reagent as controls were seeded in triplicate in a 6-well plate and grown to $80 \%$ confluence. Twenty-four hours post-transfection a vertical wound was traced in the cell monolayer with a sterile plastic tip. After 4 and $24 \mathrm{~h}$ cells were fixed with $4 \%$ paraformaldehyde in PBS pH 7.0 and monolayer restoration was imaged through an inverted phase contrast microscope (magnification, $\mathrm{x} 10$ ). The scratched area was quantified at each time point and the resulting values were graphed. To quantify migratory capacity of cells, transwell chambers (Corning) with 6.5-mm diameter and $8-\mu \mathrm{m}$ pore size polycarbonate membrane were used. MDA-MB-231 and MCF-7 cells $\left(1 \times 10^{5}\right)$ transfected with miR-18b inhibitor, scramble or siPORT transfection reagent (mock) were transferred to $0.5 \mathrm{ml}$ serum-free medium and placed in the upper chamber, whereas the lower chamber was loaded with $0.8 \mathrm{ml}$ medium containing $10 \% \mathrm{FBS}$. The total number of cells that migrated into the lower chamber was counted after $24 \mathrm{~h}$ incubation at $37^{\circ} \mathrm{C}$.

Statistical analysis. Each experiment was performed at least three times, and the results are presented as the mean \pm SD. One-way analysis of variance (ANOVA) followed by Tukey's test were used to compare the differences between means. $\mathrm{P}<0.05$ was considered as statistically significant.

\section{Results}

miRNA-18b expression is upregulated in breast cancer cell lines and clinical tumors. In our previous studies, we analyzed a limited set of clinical breast tumors and identified 54 microRNAs that exhibit a significant differential expression between tumor and non-tumor tissues (our unpublished data). Of these, miR-18b was overexpressed in breast cancer and it was selected for further analysis. Here, we studied the miR-18b levels in an independent set of clinical specimens and in five human breast cancer cell lines. We extended our analysis by assaying the miR-18b expression using qRT-PCR TaqMan microRNA assays in clinical specimens obtained from 14 human breast cancer patients who did not receive anti-neoplastic therapy prior to surgery. Tumors were stratified based on clinical subtypes as luminal, HER2-positive and triple negative. Clinical features of breast tumors including hormonal receptors status, tumor size, histology, clinical stage, and tumor grade are summarized in Table I. Our results showed that miR-18b expression was increased in breast tumors in comparison to non-tumoral tissues (Fig. 1A). Particularly, the miR-18b expression average was augmented in luminal (2.5-fold), HER2-positive (4.6-fold), and triple negative (17-fold) tumor subtypes relative to non-tumoral specimens (Fig. 1B). We found no relationship between the expression of miR-18b and clinical characteristics of the patients such as tumor grade, clinical stage, tumor size or histological subtype. Then, we analyzed the miR-18b expression in breast cancer cell lines by qRT-PCR using TaqMan microRNA assays. Results showed that miR-18b levels were significantly increased (2- to 7-fold) in MDA-MB-231, MDA-MB-453, ZR-75 and T47-D cell lines in comparison to non-tumoral breast tissues used as control samples (Fig. 1C). In contrast, miR-18b expression was similar in MCF-7 cell line and normal breast tissues. Interestingly, the triple negative MDA-MB-231 cell line and triple negative breast tumors exhibit the highest miR-18b 
A

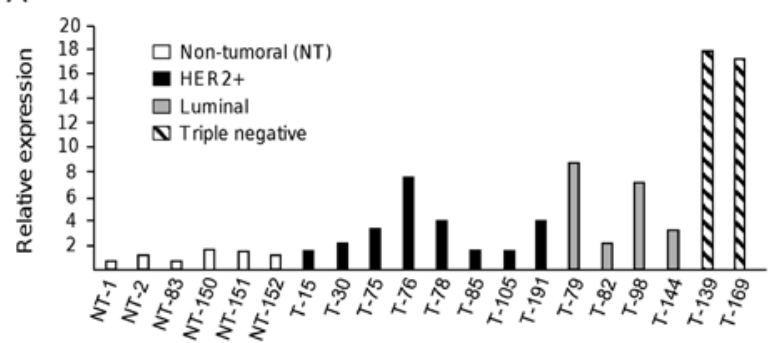

$\mathrm{C}$

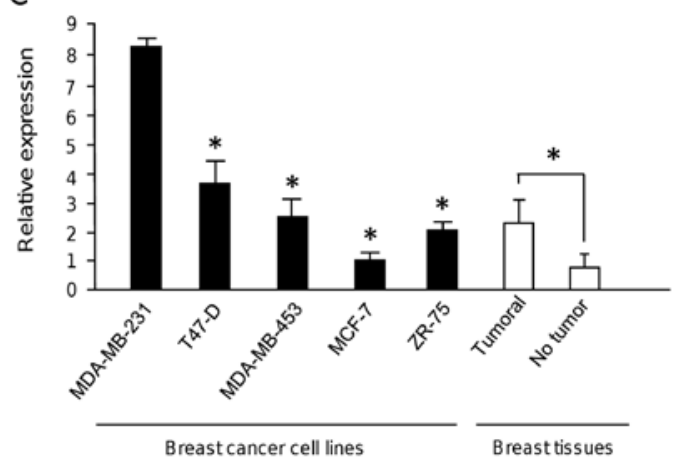

B

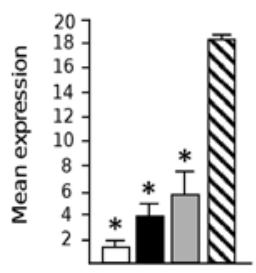

Figure 1. miR-18b is overexpressed in clinical tumors and breast cancer cell lines. (A) TaqMan microRNA assay for miR-18b expression in non-tumoral (NT) and tumor (T) breast tissues. (B) Graphical representation of mean average data in A. Breast tumors were analyzed to compare to NT tissues by measuring the relative expression and normalized with endogenous small-nucleolar RNU-44. (C) TaqMan microRNA assay for miR-18b expression in diverse breast cancer cell lines, NT and T tissues. Bars represent the means of at least three independent experiments \pm SD. ${ }^{*} \mathrm{P}<0.005$. Experiments were repeated at least twice with similar results.

expression levels. We decided to use the MDA-MB-231 cell line as model for searching potential miR-18b targets.

Transcriptional profiles of miR-18b-deficient MDA-MB-231 cells. In order to obtain a comprehensive analysis of cellular transcripts that may represent potential targets of miR-18b in triple negative breast cancer, we studied the effects of its inhibition on the transcriptome of MDA-MB-231 cells. We confirmed the effective knock-down of miR-18b expression by qRT-PCR assays using antagomiRs (data not shown). Total RNA was extracted from cells transfected with miR-18b inhibitor $(50 \mathrm{nM})$ and siPORT amine transfection agent (control) cells, and hybridized to Human Gene Expression $12 \times 135$ K DNA microarrays (NimbleGen, Roche). We performed data extraction, normalization of replicates and controls, and selection of spots with a significant modulation (cut-off of $\geq 1.5$-fold) as described in Materials and methods. Our microarray analysis identified 263 genes with a significant modulation (adjusted P-value $=0.05$ ). Of these, 43 genes were downregulated and 220 were upregulated. These results indicated that repression of miR-18b had positive effects in global gene expression of MDA-MB-231 cells, as expected for a negative regulator of gene expression. In Tables II and III we show an overview of the top 20 modulated genes in miR18b-deficient MDA-MB-231 cells.

Olfactory receptor $(O R)$ genes were upregulated in miR-18bdeficient breast cancer cells. Surprisingly, we evidenced the upregulation of 55 OR genes in MDA-MB-231 cells deficient for miR-18b (Table IV). The OR proteins are members of a large family of G-protein-coupled receptors which are expressed not only in the sensory neurons of the olfactory epithelium, but also in various other non-chemosensory tissues (17) and in tumor tissues including prostate cancer where their activation inhibits cell proliferation $(18,19)$. However, the relevance and function of OR genes is still unknown in breast cancer. Here, we found that ten upregulated ORs genes were clustered in 11q12.1 chromosome region and six were grouped in 11q24.2 locus. To understand the coordinated upregulation of these genes, we searched for miR-18b binding sites in the 3'UTR of OR genes using miRanda software (20). Intriguingly, results showed that none of modulated OR genes presented potential miR-18b binding sites. This raises the possibility that OR gene expression could be regulated by a miR-18b-mediated indirect mechanism. To test this hypothesis, we searched for miR-18b binding sites in the $3^{\prime}$ UTRs of transcription factors leading to activation of OR genes (21). Interestingly, we found that pancreatic and duodenal homeobox 1 (PDX1), a transcription factor regulating ORs, has potential binding sites for miR-18b. In agreement, we found that PDX1 gene was also up-regulated in our microarray assays (fold change $1.98 ; \mathrm{P}=0.039$ ). These data suggested that $\mathrm{OR}$ gene expression could be regulated through a miR-18b-indirect mechanism by targeting transcription factors leading to OR activation. However, further experiments are needed to support these assumptions.

miR-18b modulates genes involved in tumorigenesis. Further analysis of microarray data leads us to the identification of diverse genes involved in cancer whose expression was modulated when miR-18b expression was inhibited in breast cancer cells. In Table $\mathrm{V}$ we show an overview of upregulated genes which have been reported previously in different malignancies. These genes have been implicated in tumor growth (CHRM2 and POSTN), cell proliferation (NLRP7 and 
Table II. Top 20 of upregulated genes in miR-18b-deficient human MDA-MB-231 breast cancer cells.

\begin{tabular}{|c|c|c|c|}
\hline Gene symbol $^{\mathrm{a}}$ & Protein name ${ }^{b}$ & Fold change & P-value \\
\hline OR8D2 & Olfactory receptor, family 8 , subfamily D, member 2 & 7.10 & 0.039 \\
\hline OR8G2 & Olfactory receptor, family 8 , subfamily $\mathrm{G}$, member 2 & 6.44 & 0.011 \\
\hline OR8D1 & Olfactory receptor, family 8 , subfamily $\mathrm{D}$, member 1 & 6.36 & 0.017 \\
\hline REXO1L1 & REX1, RNA exonuclease 1 homolog-like 1 & 5.94 & 0.013 \\
\hline KRTAP13-1 & Keratin associated protein $13-1$ & 5.87 & 0.013 \\
\hline $\mathrm{ERC} 2$ & ELKS/RAB6-interacting/CAST family member 2 & 5.77 & 0.044 \\
\hline OR11H1 & Olfactory receptor, family 11 , subfamily $\mathrm{H}$, member 1 & 5.65 & 0.032 \\
\hline OR9G1 & Olfactory receptor, family 9, subfamily $\mathrm{G}$, member 1 & 5.63 & 0.021 \\
\hline KIR3DL3 & Killer cell immunoglobulin-like receptor & 5.46 & 0.047 \\
\hline OR52E2 & Olfactory receptor, family 5, subfamily E, member 2 & 5.46 & 0.046 \\
\hline NLRP7 & NLR family, pyrin domain containing 7 & 5.33 & 0.018 \\
\hline OR52J3 & Olfactory receptor, family 52 , subfamily $\mathrm{J}$, member 3 & 5.33 & 0.013 \\
\hline KCND2 & Potassium voltage-gated channel & 5.33 & 0.040 \\
\hline PRAMEF5 & PRAME family member 5 & 5.32 & 0.031 \\
\hline REG1B & Regenerating islet-derived $1 \beta$ & 5.26 & 0.014 \\
\hline OR4A47 & Olfactory receptor, family 4 , subfamily A, member 47 & 5.19 & 0.006 \\
\hline OR8H3 & Olfactory receptor, family 8 , subfamily $\mathrm{H}$, member 3 & 5.18 & 0.041 \\
\hline LOC391747 & Similar to hCG1807616; TBP-associated factor 11 & 5.04 & 0.017 \\
\hline OR4A15 & Olfactory receptor, family 4 , subfamily A, member 15 & 5.00 & 0.006 \\
\hline OR10G8 & Olfactory receptor, family 10 , subfamily $\mathrm{G}$, member 8 & 4.98 & 0.001 \\
\hline
\end{tabular}

${ }^{\mathrm{a}} \mathrm{GenBank}$ databases; ${ }^{\mathrm{b} U n i P r o t}$ database (recommended name).

Table III. Top 20 of downregulated genes in miR-18b-deficient human MDA-MB-231 breast cancer cells.

\begin{tabular}{|c|c|c|c|}
\hline Gene symbol $^{\mathrm{a}}$ & Protein name ${ }^{b}$ & Fold change & P-value \\
\hline PELP1 & Proline, glutamate and leucine rich protein 1 & -8.664 & 0.007 \\
\hline FBXW4 & F-box and WD repeat domain containing 4 & -5.560 & 0.041 \\
\hline MR1 & Major histocompatibility complex, class I-related & -4.16 & 0.044 \\
\hline MARCH1 & Membrane-associated ring finger $(\mathrm{C} 3 \mathrm{HC} 4) 1, \mathrm{E} 3$ ubiquitin protein ligase & -4.065 & 0.042 \\
\hline MAK & Male germ cell-associated kinase & -4.009 & 0.047 \\
\hline MAGED4B & Melanoma-associated antigen D 4B & -3.451 & 0.043 \\
\hline EXOC6 & Exocyst complex component 6 & -3.089 & 0.042 \\
\hline PLEKHH2 & Pleckstrin homology domain containing, family $\mathrm{H}$ member 2 & -2.919 & 0.012 \\
\hline FAM113B & Family with sequence similarity 113, member B & -2.783 & 0.031 \\
\hline BAIAP2L2 & BAI1-associated protein 2-like 2 & -2.63 & 0.043 \\
\hline THAP9 & THAP domain containing 9 & -2.547 & 0.009 \\
\hline KCNK7 & Potassium channel, subfamily K, member 7 & -2.429 & 0.044 \\
\hline C17orf57 & Chromosome 17 open reading frame 57 & -2.321 & 0.035 \\
\hline BEND2 & BEN domain containing 2 & -2.300 & 0.016 \\
\hline TMEM27 & Transmembrane protein 27 & -2.284 & 0.038 \\
\hline SOX4 & SRY (sex determining region Y)-box 4 & -2.281 & 0.040 \\
\hline BCAT1 & Branched chain aminotransferase 1 , cytosolic & -2.20 & 0.031 \\
\hline TMEM19 & Transmembrane protein 19 & -2.148 & 0.023 \\
\hline ADPGK & ADP-dependent glucokinase & -2.12 & 0.032 \\
\hline SPN & Sialophorin & -2.07 & 0.043 \\
\hline
\end{tabular}

${ }^{\mathrm{a}}$ GenBank databases; ${ }^{\mathrm{b} U n i P r o t}$ database (recommended name). 
Table IV. Upregulated olfactory receptor genes in miR-18bdeficient MDA-MB-231 breast cancer cells.

\begin{tabular}{|c|c|c|c|}
\hline Gene symbol & Fold change & P-value & Locus \\
\hline$\underline{\mathrm{OR} 8 \mathrm{D} 2}$ & 7.10 & 0.039 & $11 \mathrm{q} 24.2$ \\
\hline$\underline{\mathrm{OR} 8 \mathrm{G} 2}$ & 6.44 & 0.011 & $11 \mathrm{q} 24.2$ \\
\hline OR8D1 & 6.36 & 0.017 & $11 \mathrm{q} 24.2$ \\
\hline OR11H1 & 5.65 & 0.032 & $22 q 11.1$ \\
\hline OR9G1 & 5.63 & 0.021 & $11 q 12.1$ \\
\hline OR52E2 & 5.46 & 0.046 & $11 \mathrm{p} 15.4$ \\
\hline OR52J3 & 5.33 & 0.013 & $11 \mathrm{p} 15.4$ \\
\hline OR4A47 & 5.19 & 0.006 & $11 \mathrm{p} 11.2$ \\
\hline OR8H3 & 5.18 & 0.041 & $11 \mathrm{q} 12.1$ \\
\hline OR4A15 & 5.00 & 0.006 & $11 q 11$ \\
\hline$\underline{\text { OR10G8 }}$ & 4.98 & 0.001 & $11 \mathrm{q} 24.2$ \\
\hline OR2T8 & 4.97 & 0.035 & 1q44 \\
\hline OR4K2 & 4.92 & 0.049 & $14 q 11.2$ \\
\hline OR1C1 & 4.71 & 0.036 & $1 \mathrm{q} 44$ \\
\hline OR5J2 & 4.56 & 0.036 & $11 \mathrm{q} 12.1$ \\
\hline OR1S1 & 4.49 & 0.040 & $11 \mathrm{q} 12.1$ \\
\hline OR4Q3 & 4.44 & 0.001 & $14 q 11.2$ \\
\hline OR10H4 & 4.36 & 0.050 & $19 p 13.12$ \\
\hline OR10H3 & 4.24 & 0.014 & $19 \mathrm{p} 13.12$ \\
\hline OR5D16 & 4.23 & 0.020 & $11 q 11$ \\
\hline OR8H2 & 4.20 & 0.007 & $11 q 12.1$ \\
\hline OR6K2 & 4.17 & 0.015 & 1q23.1 \\
\hline OR6N1 & 4.15 & 0.025 & $1 q 23.1$ \\
\hline OR7C2 & 4.12 & 0.010 & $19 \mathrm{p} 13.12$ \\
\hline OR10K2 & 3.95 & 0.038 & $1 q 23.1$ \\
\hline OR4C13 & 3.95 & 0.004 & $11 \mathrm{p} 11.12$ \\
\hline OR56A4 & 3.93 & 0.026 & $11 \mathrm{p} 15.4$ \\
\hline OR2T27 & 3.89 & 0.036 & $1 q 44$ \\
\hline OR52K2 & 3.84 & 0.022 & $11 \mathrm{p} 15.4$ \\
\hline OR1E1 & 3.77 & 0.016 & $17 \mathrm{p} 13.2$ \\
\hline OR2J3 & 3.69 & 0.019 & $6 \mathrm{p} 22.1$ \\
\hline OR6N2 & 3.66 & 0.043 & $1 \mathrm{q} 23.1$ \\
\hline$\underline{\mathrm{OR} 8 \mathrm{~B} 3}$ & 3.45 & 0.046 & $11 \mathrm{q} 24.2$ \\
\hline OR4F17 & 3.36 & 0.029 & $19 p 13.3$ \\
\hline OR8H1 & 3.49 & 0.011 & $11 \mathrm{q} 12.1$ \\
\hline OR10Q1 & 3.35 & 0.023 & $11 \mathrm{q} 12.1$ \\
\hline OR5M8 & 3.31 & 0.017 & $11 \mathrm{q} 12.1$ \\
\hline OR5M11 & 2.69 & 0.010 & $11 q 12.1$ \\
\hline OR5AR1 & 2.74 & 0.028 & $11 q 12.1$ \\
\hline OR14I1 & 3.31 & 0.040 & $1 q 44$ \\
\hline OR1J4 & 3.23 & 0.026 & $9 q 33.2$ \\
\hline OR5AU1 & 3.11 & 0.034 & $14 q 11.2$ \\
\hline OR2T29 & 3.00 & 0.004 & $1 q 44$ \\
\hline OR8B8 & 2.40 & 0.009 & $11 \mathrm{q} 24.2$ \\
\hline OR4C46 & 2.20 & 0.003 & $11 \mathrm{p} 11.12$ \\
\hline OR6K3 & 2.16 & 0.001 & 1q23.1 \\
\hline OR2T5 & 2.10 & 0.015 & $1 \mathrm{q} 44$ \\
\hline OR10S1 & 2.09 & 0.042 & $11 \mathrm{q} 24.1$ \\
\hline OR3A2 & 2.02 & 0.020 & $17 \mathrm{p} 13.3$ \\
\hline
\end{tabular}

Table IV. Continued.

\begin{tabular}{lccc}
\hline Gene symbol & Fold change & P-value & Locus \\
\hline OR2J2 & 1.98 & 0.036 & $6 \mathrm{p} 22.1$ \\
OR2AK2 & 1.88 & 0.035 & $1 \mathrm{q} 44$ \\
OR5D14 & 1.82 & 0.044 & $11 \mathrm{q} 11$ \\
OR1L6 & 1.79 & 0.025 & $9 \mathrm{q} 33.2$ \\
OR13C5 & 1.60 & 0.028 & $9 \mathrm{q} 31.1$ \\
OR6Y1 & 1.52 & 0.035 & $1 \mathrm{q} 23.1$ \\
\hline
\end{tabular}

Genes clustered in 11q24.2 chromosomal region are underlined. Genes clustered in 11q12.1 chromosomal region are shown in bold.

CHMR2), anoikis (OLFM3), apoptosis (REG1B, SCN3B and POSTN), and angiogenesis (KLK3, CHRM2 and POSTN). Interestingly, eight genes (KIR3DL3, NLRP7, KLK3, OLFM3, SEMG1, CRX, POSTN and CEACAM5) have been shown to be involved in invasion and metastasis of cancer cells. To determine whether the overexpression of these genes was related to direct binding of miR-18b, we searched for potential miR-18b binding sites in their 3'UTR region. Eleven genes were predicted to have binding sites for miR-18b, nine of them with one site and two with more than one binding site. Among these, four genes (KIR3DL3, KLK3, CRX and POSTN) were implicated in invasion and metastasis of cancer cells. For instance, the KLK3 gene encodes prostatespecific antigen (PSA), which is a serin protease that has been established as a tumor marker of prostatic adenocarcinoma. This protein was found elevated in women with renal cell carcinoma (22), it has been shown to exert anti-angiogenic properties, and to present mutations in breast tumors (23). Another upregulated gene, POSTN encodes periostin, a secretory protein which has been suggested to function as a cell adhesion molecule participating in osteoblast recruitment, attachment and spreading $(24,25)$. POSTN was found overexpressed in several cancers with enhanced invasiveness, and correlated with metastasis in colorectal and liver cancers, as well in oral cancer cell lines (26).

Knockdown of miR-18b suppresses cell migration in vitro. Our transcriptional profiling of MDA-MB-231 cells with reduced miR-18b expression revealed that a set of modulated genes have key roles in migration and invasion of cancer cells. In order to evaluate whether miR-18b could be implicated in the regulation of migration properties of breast cancer cells, we performed scratch/wound-healing and Transwell assays in MDA-MB-231 cells with reduced expression of miR-18b. We first evaluated the effect of increasing concentrations of antagomiR-18b in cell viability by MTT assay. No significant changes in cell viability were observed using a range of concentrations (25-200 mM) of miR-18b inhibitor in metastatic MDA-MB-231 cells (Fig. 2A). Similar results were obtained in the MCF-7 breast cancer cell line (Fig. 2E). Then, we performed a scratch/wound-healing assay to evaluate whether the suppression of miR-18b expression could have effects on cancer cell migration. Monolayers of MDA-MB-231 and MCF-7 cells non-transfected and transfected with miR-18b 
Table V. The genes modulated by miR-18b inhibition with a role in human cancers.

\begin{tabular}{|c|c|c|c|c|c|c|}
\hline $\begin{array}{l}\text { Gene } \\
\text { symbol }^{\mathrm{a}}\end{array}$ & $\begin{array}{l}\text { Fold } \\
\text { change }\end{array}$ & P-value & Description & Gene function related to cancer & Refs. & $\begin{array}{l}\text { miR-18b } \\
\text { binding } \\
\text { sites }^{\mathrm{b}}\end{array}$ \\
\hline ERC2 & 5.77 & 0.044 & $\begin{array}{l}\text { ELKS/RAB6-interacting/ } \\
\text { CAST family member } 2\end{array}$ & $\begin{array}{l}\text { Promotes oncogenesis in papillary } \\
\text { thyroid carcinoma by fusion } \\
\text { of ELKS to RET. }\end{array}$ & $(40)$ & 1 \\
\hline KIR3DL3 & 5.46 & 0.047 & $\begin{array}{l}\text { Killer cell immunoglobulin- } \\
\text { like receptor }\end{array}$ & $\begin{array}{l}\text { Interactions with MHC-I on melanoma } \\
\text { inhibit tumor cells lysis by NK and T cells. } \\
\text { Interactions between KIR and HLA in NK } \\
\text { cell-controls uveal melanoma metastasis. }\end{array}$ & $(41,42)$ & 1 \\
\hline NLRP7 & 5.33 & 0.018 & $\begin{array}{l}\text { NLR family, pyrin domain } \\
\text { containing } 7\end{array}$ & $\begin{array}{l}\text { Cell proliferation and tumorigenesis in } \\
\text { testicular germ cell tumor. } \\
\text { Promote tumor invasion and poor } \\
\text { prognosis in endometrial cancer. }\end{array}$ & $(43,44)$ & None \\
\hline $\mathrm{KCND} 2$ & 5.33 & 0.040 & $\begin{array}{l}\text { Potassium voltage-gated } \\
\text { channel subfamily D2 }\end{array}$ & $\begin{array}{l}\text { Participates in brain cancer-induced } \\
\text { cachexia. }\end{array}$ & $(45)$ & 1 \\
\hline REG1B & 5.26 & 0.014 & $\begin{array}{l}\text { Regenerating islet- } \\
\text { derived } 1 \beta\end{array}$ & $\begin{array}{l}\text { Regulates IL- } 6 \text { and enhance the chemo- } \\
\text { and radio-sensitivity on squamous } \\
\text { esophageal cancer. }\end{array}$ & $(46,47)$ & 1 \\
\hline KIR2DS2 & 4.85 & 0.020 & $\begin{array}{l}\text { Killer cell immunoglobulin- } \\
\text { like receptor }\end{array}$ & $\begin{array}{l}\text { Associated with better response to } \\
\text { treatment and prolonged survival } \\
\text { in non-small cell lung carcinoma. } \\
\text { Activated KIR genes are associated } \\
\text { with reduced risk for developing } \\
\text { acute lymphoblastic leukemia. }\end{array}$ & $(48,49)$ & None \\
\hline KLK3 & 4.52 & 0.013 & $\begin{array}{l}\text { Prostate-specific antigen } \\
\text { (PSA). Kallikrein-related } \\
\text { peptidase } 3\end{array}$ & $\begin{array}{l}\text { Contribute to bone metastasis in prostate } \\
\text { cancer. Modulates cell invasion of prostate } \\
\text { cancer cells. High levels of PSA may slow } \\
\text { down prostate cancer progression by } \\
\text { inhibiting angiogenesis. Regulates } \\
\text { androgen receptor in prostate cancer. } \\
\text { Decreased expression in ovarian tumors. } \\
\text { Favorable indicator of prognosis in } \\
\text { breast cancer. }\end{array}$ & $(50-54)$ & 1 \\
\hline PRAMEF4 & 4.49 & 0.012 & PRAME family member 4 & $\begin{array}{l}\text { Correlates with poor prognosis } \\
\text { in head and neck cancer. }\end{array}$ & $(55)$ & None \\
\hline CHRM2 & 4.47 & 0.005 & $\begin{array}{l}\text { Muscarinic acetylcholine } \\
\text { receptor M2 }\end{array}$ & $\begin{array}{l}\text { Involved in proliferation of murine } \\
\text { adenocarcinoma cell lines. Involved in } \\
\text { growth, proliferation and angiogenesis } \\
\text { in breast cancer cells. Involved in } \\
\text { inhibition of glioma cell proliferation. } \\
\text { Involved in cell proliferation of chronic } \\
\text { myelogenous leukemia. }\end{array}$ & $(56-60)$ & 1 \\
\hline OLFM3 & 4.44 & 0.037 & Olfactomedin 3/noelin-3 & $\begin{array}{l}\text { Contributes to anoikis-resistance in } \\
\text { squamous lung carcinoma. Olfml3 } \\
\text { targeting inhibits endothelioma } \\
\text { cell migration, tumor growth and } \\
\text { sprouting. OLFM3 is pro-angiogenic. }\end{array}$ & $(61,62)$ & None \\
\hline PCDH15 & 4.12 & 0.014 & Protocadherin 15 & Potential marker for NK/T cell lymphomas. & $(63)$ & 1 \\
\hline
\end{tabular}


Table V. Continued.

\begin{tabular}{|c|c|c|c|c|c|c|}
\hline $\begin{array}{l}\text { Gene } \\
\text { symbol }^{\mathrm{a}}\end{array}$ & $\begin{array}{l}\text { Fold } \\
\text { change }\end{array}$ & P-value & Description & Gene function related to cancer & Refs. & $\begin{array}{l}\text { miR-18b } \\
\text { binding } \\
\text { sites }^{\mathrm{b}}\end{array}$ \\
\hline SCN3B & 3.96 & 0.029 & Sodium channel subunit $\beta-3$ & $\begin{array}{l}\text { Mediates a p53-dependent apoptotic } \\
\text { pathway (pro-apoptotic) in colorectal } \\
\text { carcinoma cell line HCT } 116 .\end{array}$ & (64) & 1 \\
\hline SEMG1 & 3.86 & 0.005 & Semenogelin I & $\begin{array}{l}\text { Overexpressed in OH-1 SCLC lung cancer } \\
\text { cell lines and associated with cell surface } \\
\text { adhesion complexes. Mutated in colorectal } \\
\text { cancer. Inhibits motility of sperm cells. } \\
\text { SEMG1 inhibits prostate-tumor growth. }\end{array}$ & $(65-69)$ & None \\
\hline CRX & 3.82 & 0.012 & Cone-rod homeobox protein & $\begin{array}{l}\text { Overexpressed in medulloblastomas. } \\
\text { Upregulated in retinoblastoma tumors. } \\
\text { Metastatic retinoblastoma marker. }\end{array}$ & $(70-72)$ & 2 \\
\hline KLK15 & 3.78 & 0.003 & $\begin{array}{l}\text { Kallikrein-related } \\
\text { peptidase } 15\end{array}$ & $\begin{array}{l}\text { Upregulated by steroid hormones in the } \\
\text { LNCaP prostate cancer cell line; associated } \\
\text { with more aggressive forms of prostate } \\
\text { cancer. Marker of unfavorable prognosis } \\
\text { in ovarian cancer. Prognostic marker for } \\
\text { progression-free survival in patients with } \\
\text { radical prostatectomy. Favorable } \\
\text { prognostic marker for breast cancer. }\end{array}$ & $(73-76)$ & None \\
\hline POSTN & 3.77 & 0.043 & Periostin & $\begin{array}{l}\text { Enhances invasion, angiogenesis and } \\
\text { metastasis in oral cancer and head and } \\
\text { neck squamous cell carcinoma. Promotes } \\
\text { the metastatic growth of colon cancer. } \\
\text { It is required for cancer stem cell } \\
\text { maintenance, and blocking its function } \\
\text { prevents metastasis. Reduces cell } \\
\text { migration and suppressed metastasis } \\
\text { in vivo. Inhibits breast cancer progression } \\
\text { and metastasis by anti-periostin } \\
\text { in a murine model. }\end{array}$ & $(77-80)$ & 1 \\
\hline PCDHB2 & 2.39 & 0.019 & Protocadherin beta 2 & $\begin{array}{l}\text { Mutation of PCDHB2 (cell adhesion } \\
\text { protein) in pancreatic cancers. }\end{array}$ & $(81)$ & None \\
\hline C1QTNF4 & 2.16 & 0.010 & $\begin{array}{l}\text { C1q and tumor necrosis } \\
\text { factor related protein } 4\end{array}$ & $\begin{array}{l}\text { Stimulates the STAT3 and NF- } \kappa \mathrm{B} \\
\text { pathways and promotes cell survival } \\
\text { in human cancer cells. }\end{array}$ & $(82)$ & None \\
\hline FOXD4L4 & 1.95 & 0.010 & Forkhead box D4-like 4 & $\begin{array}{l}\text { FOX4DL4 gene amplification in pilocytic } \\
\text { astrocytoma. Hypermethylated in } \\
\text { ovarian tumors. }\end{array}$ & $(83-85)$ & 3 \\
\hline CEACAM5 & 1.78 & 0.034 & $\begin{array}{l}\text { Carcinoembryonic antigen- } \\
\text { related cell adhesion } \\
\text { molecule } 5\end{array}$ & $\begin{array}{l}\text { Methylated in non-small cell lung cancer } \\
\text { tumors. Implied in bad prognosis in patients } \\
\text { with adenocarcinoma. Overexpression } \\
\text { enhances metastasis in coloncarcinoma. } \\
\text { Brain metastasis development and } \\
\text { poor survival associated with } \\
\text { CEA level in NSCLC. }\end{array}$ & $(86-88)$ & None \\
\hline
\end{tabular}


A

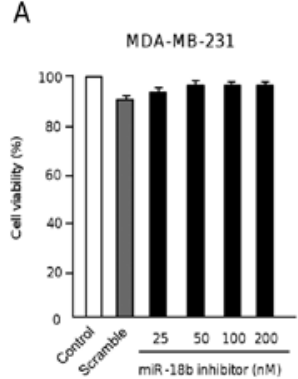

E

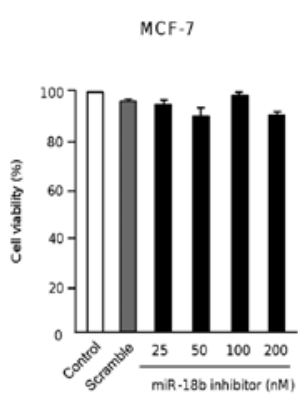

B Control

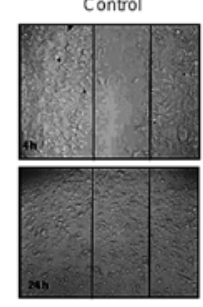

$\mathrm{F}$

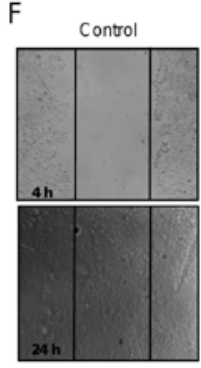

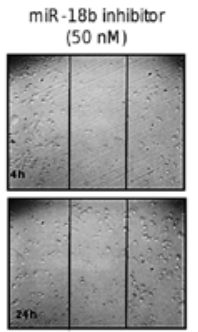

miR $-18 \mathrm{~b}$ inhibitor $(50 \mathrm{nM})$

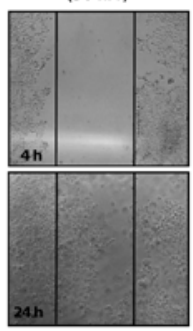

C

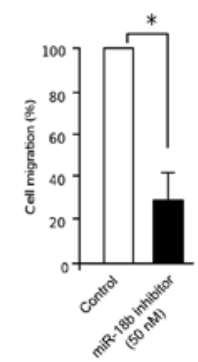

G

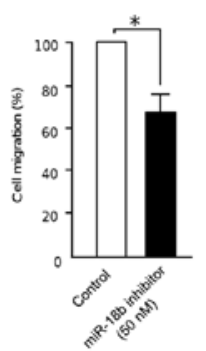

D

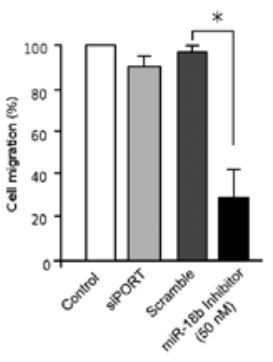

$\mathrm{H}$

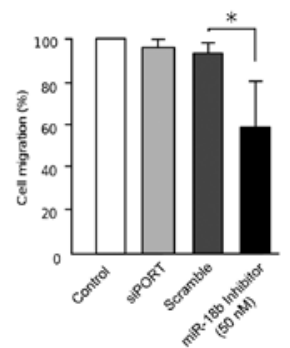

Figure 2. Knockdown of miR-18b suppresses cell migration. MTT cell viability assays of (A) MDA-MB-231 and (E) MCF-7 cells transfected with different concentrations (50-200 nM) of miR-18b inhibitor. Scratch/wound-healing assays of (B) MDA-MB-231 and (F) MCF-7 cell monolayers transfected with miR$18 \mathrm{~b}$ inhibitor $(50 \mathrm{nM})$ or treated with transfectant agent as control. Graphical representation of migrating (C) MDA-MB-231 and (G) MCF-7 breast cancer cells after wound-healing. Graphical representation of cell migration in transwell chambers of (D) MDA-MB-231 and (H) MCF-7 cells. Percent of cell migration is shown with bars for each experiment. Bars represent the means of three independent experiments $\pm \mathrm{SD}$. ${ }^{*} \mathrm{P}<0.005$.

inhibitor were grated, and the wounded areas of the cell monolayer were analyzed after $24 \mathrm{~h}$. Results showed that the formation of monolayers was significantly delayed about 70 and 30\% in MDA-MB-231 and MCF-7 cells transfected with miR-18b inhibitor, respectively, in comparison with control cells (Fig. 2B and F). By using Transwell chamber assays, we found that the number of migratory cells that crossed the membrane after 4 and $24 \mathrm{~h}$ was reduced in MDA-MB-231 (75\%) and MCF-7 (40\%) cells in comparison with controls confirming that miR-18b abolishment has negative effects in cell migration (Fig. 2D and $\mathrm{H}$ ). These findings suggested that miR-18b is able to modulate the expression of genes that are important for migration of cancer cells in vitro.

\section{Discussion}

microRNA expression is frequently deregulated in breast cancer where they play key roles in tumorigenesis acting as oncogenes and tumor suppressors. In this study, we showed that miR-18b is commonly overexpressed in breast cancer cell lines and in clinical tumors, particularly in triple negative clinical specimens (17-fold). We found an inverse correlation between miR-18b expression and hormonal receptors and HER2/neu status in breast cell lines and tumors (Fig. 1). These data are in agreement with a previous study which reports that ER- $\alpha$ is a target of miR-18a and miR-18b suggesting that inhibition of this receptor in triple negative breast cancer may be due, at least in part, by miR-18b (13). Moreover, in a study of 204 lymph node-negative breast cancers, authors found an association among higher expression of miR-18b with negative expression of ER and strongly associated with basal-like breast cancer features (27), in agreement with our results. We showed that miR-18b is overexpressed in triple negative breast tumors. Triple negative breast cancer refers to a heterogeneous group of tumors that do not express estrogen, progesterone or HER2/neu receptors, accounting for approximately $12-15 \%$ of breast cancer diagnoses (28). It represents the most aggressive subtype of breast cancer, and is associated with high rates of mortality and poor survival. Notably, no specific therapeutics targets have been identified in triple negative tumors, thus treatment is restricted to conventional chemotherapy. Therefore, the search for novel potential therapeutic targets represents today a challenge for oncology community.

In order to identify potential targets of miR-18b that could represent novel therapeutic targets in triple negative breast cancer, we suppressed its expression in MDA-MB-231 cells using antagomiRs and performed a genome-wide analysis using DNA microarrays. Our analysis showed that several genes with key roles in cancer were significantly modulated (Table V). In addition, a set of 55 OR genes were also found as regulated in miR-18b-deficient cells. The OR gene family is the largest family in the genome with more than 800 genes located in clusters that are dispersed across almost all chromosomes. Although the majority of OR members are expressed on the olfactory sensory neurons in the olfactory epithelium, they are also expressed in a large number of different tissues, but their functions remain unclear. It has been suggested that they may control cell positioning during embryogenesis (29). Of interest, the expression of ORs has been also reported in cancer. Previous studies detected the expression of ORs in human primordial germ cells and prostate cancer $(30,31)$. In a recent study it was reported that the activation of an OR (PSGR/OR51E2) inhibits proliferation of 
prostate cancer cells (18). In addition, four microRNA:mRNA modules containing the olfactory transduction pathway, are over-represented in metastatic prostate cancer (19). Most of the 55 upregulated ORs detected in this study were clustered in 11q12.1 and 11q24.2 chromosome regions, suggesting that a gain or loss of these genomic regions could explain the changes in their expression. The 11q12.1 locus is defined as an overlapping region of imbalance involved in testicular germ cell tumors (32), whereas homozygous loss of 11q24.2 region was observed in uterine leiomyosarcoma (33). OR genes located on 11q12.1 have been already reported as overexpressed in breast tumors. Of a set of 862 differentially expressed genes, 34 ORs were found to have elevated expression in breast tumors with CHEK2 1100delC mutation, where 16 ORs resided on chromosome 11, and 5 in a region flanking the centromere region 11.p11.2-11.q12.1 (34). Our results on the identification of OR genes modulated in miR-18b-deficient cells indicate that they could be involved in tumorigenesis, however additional experiments are needed to clarify their role in breast cancer. The absence for potential miR-18b binding sites in the OR genes suggested that they could be modulated by an miR-18b-driven indirect mechanism. Plessy et al (21) found binding sites for several transcription factors on OR promoters that may control their transcription. In particular, a binding site motif for PDX1 homeobox transcription factor was found in the promoter of mouse and human olfactory epithelium (MOE). PDX1 participates during branching morphogenesis in the developing mouse embryonic pancreas (35). In cancer, PDX1 is activated at various stages of gastric carcinogenesis (36), and it was suggested as a novel tumor suppressor in gastric cancer (37). It was also involved in pancreas development, in pediatric solid pseudopapillary tumors (38), and in precursor lesions of ductal adenocarcinomas (39). In our study, we found that PDX1 was upregulated after inhibition of miR-18b. From these findings, we suggested that miR-18b could indirectly regulate OR genes by direct modulation of PDX1, however, additional experimentation is needed to corroborate this hypothesis.

We have shown that the inhibition of miR-18b induces the modulation of genes with key roles in cancer. These genes have been implicated in tumor growth (CHRM2 and POSTN), cell proliferation (NLRP7 and CHMR2), anoikis (OLFM3), apoptosis (REG1B, SCN3B and POSTN), and angiogenesis (KLK3, CHRM2 and POSTN). Notably, eight genes (KIR3DL3, NLRP7, KLK3, OLFM3, SEMG1, CRX, POSTN and CEACAM5) are involved in invasion and metastasis of cancer cells (Table V). Moreover, these genes contain potential binding sites for miR-18b which strongly suggested that they could be targets of miR-18b. Our findings using wound-healing assays in miR-18b depleted cells showed that cell migration was significantly affected. By Transwell chamber assay, we corroborated the impact of miR-18b inhibition on the capacity of migration in MDA-MB-231 and MCF-7 cells. In both assays, results showed that the formation of monolayer was delayed about $40-75 \%$ in miR-18b-deficient cells in comparison to control migrating cells. Taken together, our findings strengthened the view that miR-18b is able to modulate the expression of genes that are important for migration of triple negative breast cancer cells in vitro.

\section{Acknowledgements}

We thank the Autonomous University of Mexico City and the Instituto de Ciencia y Tecnología del Distrito Federal, Mexico (grants ICyTDF/328/2011 and PIUTE10-147) for support. This study was supported by CONACyT FONSEC SALUD 115306 and 115591 grants. Miguel A. Fonseca-Sánchez and Ali Flores-Pérez were supported by ICYT-DF (179/2011). Zaira E. Arellano-Anaya was supported by a postdoctoral fellowship from CONACyT.

\section{References}

1. Hammond SM: RNAi, microRNAs, and human disease. Cancer Chemother Pharmacol 58: S63-S68, 2006.

2. Tanzer A and Stadler PF: Molecular evolution of a microRNA cluster. J Mol Biol 339: 327-335, 2004

3. Mendell JT: miRiad roles for the miR-17-92 cluster in development and disease. Cell 133: 217-222, 2008.

4. Ventura A, Young AG, Winslow MM, Lintault L, Meissner A, Erkeland SJ, Newman J, Bronson RT, Crowley D, Stone JR, Jaenisch R, Sharp PA and Jacks T: Targeted deletion reveals essential and overlapping functions of the miR-17 through 92 family of miRNA clusters. Cell 132: 875-886, 2008.

5. Tatsuguchi M, Seok HY, Callis TE, Thomson JM, Chen JF, Newman M, Rojas M, Hammond SM and Wang DZ: Expression of microRNAs is dynamically regulated during cardiomyocyte hypertrophy. J Mol Cell Cardiol 42: 1137-1141, 2007.

6. Otaegui D, Baranzini SE, Armañanzas R, Calvo B, MuñozCulla M, Khankhanian P, Inza I, Lozano JA, Castillo-Triviño T, Asensio A, Olaskoaga J and López de Munain A: Differential micro RNA expression in PBMC from múltiple sclerosis patients. PloS One 4: e6309, 2009.

7. Zhang ZZ, Liu X, Wang DQ, Teng MK, Niu LW, Huang AL and Liang Z: Hepatitis B virus and hepatocellular carcinoma at the miRNA level. World J Gastroenterol 17: 3353-3358, 2011.

8. Guo J, Miao Y, Xiao B, Huan R, Jiang Z, Meng D and Wang Y: Differential expression of microRNA species in human gastric cancer versus non-tumorous tissues. J Gastroenterol Hepatol 24: 652-657, 2009.

9. Kim TH, Kim YK, Kwon Y, Heo JH, Kang H, Kim G and An HJ: Deregulation of miR-519a, 153, and 485-5p and its clinicopathological relevance in ovarian epithelial tumours. Histopathology 57: 734-743, 2010.

10. Sand M, Skrygan M, Sand D, Georgas D, Hahn SA, Gambichler T, Altmeyer P and Bechara FG: Expression of microRNAs in basal cell carcinoma. Br J Dermatol 167: 847-855, 2012.

11. Wang YX, Zhang XY, Zhang BF, Yang CQ, Chen XM and Gao HJ: Initial study of microRNA expression profiles of colonic cancer without lymph node metastasis. J Dig Dis 11: 50-54, 2010.

12. He X, DiMeco F, Vescovi A, Heth J, Muraszko K and Fan X: MIR-18b regulates glioblastoma neurosphere growth through NOTCH2, NEDD9, and MEKK1. Neuro Oncol 14 (Suppl 6): vi142-vi152, 2012.

13. Leivonen SK, Mäkelä R, Ostling $P$, Kohonen $P$, Haapa-Paananen $S$, Kleivi K, Enerly E, Aakula A, Hellström K, Sahlberg N Kristensen VN, Børresen-Dale AL, Saviranta P, Perälä M and Kallioniemi O: Protein lysate microarray analysis to identify microRNAs regulating estrogen receptor signaling in breast cancer cell lines. Oncogene 28: 3926-3936, 2009.

14. Yoshimoto N, Toyama T, Takahashi S, Sugiura H, Endo Y, Iwasa M, Fujii Y and Yamashita H: Distinct expressions of microRNAs that directly target estrogen receptor $\alpha$ in human breast cancer. Breast Cancer Res Treat 130: 331-339, 2011.

15. Cookson VJ, Bentley MA, Hogan BV, Horgan K, Hayward BE, Hazelwood LD and Hughes TA: Circulating microRNA profiles reflect the presence of breast tumours but not the profiles of microRNA within the tumours. Cell Oncol 35: 301-308, 2012.

16. Simon A and Biot E: ANAIS: Analysis of NimbleGen arrays interface. Bioinformatics 26: 2468-2469, 2010.

17. Kang $\mathrm{N}$ and Koo J: Olfactory receptors in non-chemosensory tissues. BMB Rep 5: 612-622, 2012.

18. Neuhaus EM, Zhang W, Gelis L, Deng Y, Noldus J and Hatt H: Activation of an olfactory receptor inhibits proliferation of prostate cancer cells. J Biol Chem 284: 16218-16225, 2009. 
19. Zhang W, Edwards A, Fan W, Flemington EK and Zhang K: miRNA-mRNA correlation-network modules in human prostate cancer and the differences between primary and metastatic tumor subtypes. PLoS One 7: e40130, 2012.

20. Betel D, Wilson M, Gabow A, Marks DS and Sander C: The microRNA.org resource: targets and expression. Nucleic Acids Res 36: 149-153, 2008.

21. Plessy C, Pascarella G, Bertin N, Akalin A, Carrieri C, Vassalli A, Lazarevic D, Severin J, Vlachouli C, Simone R, Faulkner GJ, Kawai J, Daub CO, Zucchelli S, Hayashizaki Y, Mombaerts P, Lenhard B, Gustincich S and Carninci P: Promoter architecture of mouse olfactory receptor genes. Genome Res 22: 486-497, 2012.

22. Clements J, Ward G, Kaushal A, Hi SI, Kennett C and Nicol D: A prostate-specific antigen-like protein associated with renal cell carcinoma in women. Clin Cancer Res 3: 1427-1431, 1997.

23. Majumdar S and Diamandis EP: The promoter and the enhancer region of the KLK3 (prostate specific antigen) gene is frequently mutated in breast tumours and in breast carcinoma cell lines. $\mathrm{Br}$ J Cancer 79: 1594-1602, 1999.

24. Takeshita S, Kikuno R, Tezuka K and Amann E: Osteoblastspecific factor 2: cloning of a putative bone adhesion protein with homology with the insect protein fasciclin I. Biochem J 15 : 271-278, 1993

25. Horiuchi K, Amizuka N, Takeshita S, Takamatsu H, Katsuura M, Ozawa H, Toyama Y, Bonewald LF and Kudo A: Identification and characterization of a novel protein, periostin, with restricted expression to periosteum and periodontal ligament and increased expression by transforming growth factor beta. J Bone Miner Res 14: 1239-1249, 1999.

26. Siriwardena BS, Kudo Y, Ogawa I, Kitagawa M, Kitajima S, Hatano H, Tilakaratne WM, Miyauchi M and Takata T: Periostin is frequently overexpressed and enhances invasion and angiogenesis in oral cancer. Br J Cancer 95: 1396-1403, 2006.

27. Jonsdottir K, Janssen SR, Da Rosa FC, Gudlaugsson E, Skaland I, Baak JP and Janssen EA: Validation of expression patterns for nine miRNAs in 204 lymph-node negative breast cancers. PLoS One 7: e48692, 2012.

28. Fornier $\mathrm{M}$ and Fumoleau P: The paradox of triple negative breast cancer: novel approaches to treatment. Breast J 1: 41-51, 2012.

29. Dreyer WJ: The area code hypothesis revisited: olfactory receptors and other related transmembrane receptors may function as the last digits in a cell surface code for assembling embryos. Proc Natl Acad Sci USA 95: 9072-9077, 1998

30. Goto T, Salpekar A and Monk M: Expression of a testis-specific member of the olfactory receptor gene family in human primordial germ cells. Mol Hum Reprod 7: 553-558, 2001.

31. Weng J, Wang J, Hu X, Wang F, Ittmann M and Liu M: PSGR2, a novel G-protein coupled receptor, is overexpressed in human prostate cancer. Int J Cancer 118: 1471-1480, 2006

32. McIntyre A, Summersgill B, Jafer O, Rodriguez S, Zafarana G, Oosterhuis JW, Gillis AJ, Looijenga L, Cooper C, Huddart R, Clark J and Shipley J: Defining minimum genomic regions of imbalance involved in testicular germ cell tumors of adolescents and adults through genome wide microarray analysis of cDNA clones. Oncogene 23: 9142-9147, 2004.

33. Raish M, Khurshid M, Ansari MA, Chaturvedi PK, Bae SM, Kim JH, Park EK, Park DC and Ahn WS: Analysis of molecular cytogenetic alterations in uterine leiomyosarcoma by array-based comparative genomic hybridization. J Cancer Res Clin Oncol 138: 1173-1186, 2012.

34. Muranen TA, Greco D, Fagerholm R, et al: Breast tumors from CHEK2 110delC-mutation carriers: genomic landscape and clinical implications. Breast Cancer Res 13: R90, 2011.

35. Wescott MP, Rovira M, Reichert M, von Burstin J, Means A, Leach SD and Rustgi AK: Pancreatic ductal morphogenesis and the Pdx1 homeodomain transcription factor. Mol Biol Cell 20: 4838-4844, 2009.

36. Sakai H, Eishi Y, Li XL, Akiyama Y, Miyake S, Takizawa T, Konishi N, Tatematsu M, Koike M and Yuasa Y: PDX1 homeobox protein expression in pseudopyloric glands and gastric carcinomas. Gut 53: 323-330, 2004

37. Ma J, Chen M, Wang J, Xia HH, Zhu S, Liang Y, Gu Q, Qiao L, Dai Y, Zou B, Li Z, Zhang Y, Lan H and Wong BC: Pancreatic duodenal homeobox-1 (PDX1) functions as a tumor suppressor in gastric cancer. Carcinogenesis 29: 1327-1333, 2008.

38. Galmiche L, Sarnacki S, Verkarre V, Boizet B, Duvillie B, Fabre $\mathrm{M}$ and Jaubert F: Transcription factors involved in pancreas development are expressed in paediatric solid pseudopapillary tumours. Histopathology 53: 318-324, 2008.
39. Park JY, Hong SM, Klimstra DS, Goggins MG, Maitra A and Hruban RH: Pdx1 expression in pancreatic precursor lesions and neoplasms. Appl Immunohistochem Mol Morphol 19: 444-449, 2011.

40. Nakata T, Kitamura Y, Shimizu K, Tanaka S, Fujimori M, Yokoyama S, Ito K and Emi M: Fusion of a novel gene, ELKS, to RET due to translocation $\mathrm{t}(10 ; 12)(\mathrm{q} 11 ; \mathrm{p} 13)$ in a papillary thyroid carcinoma. Genes Chromosomes Cancer 25: 97-103, 1999.

41. Bakker AB, Phillips JH, Figdor CG and Lanier LL: Killer cell inhibitory receptors for MHC class I molecules regulate lysis of melanoma cells mediated by NK cells, gamma delta T cells, and antigen-specific CTL. J Immunol 160: 5239-5245, 1998.

42. Maat W, van der Slik AR, Verhoeven DH, Alizadeh BZ, Ly LV, Verduijn W, Luyten GP, Mulder A, van Hall T, Koning F, Jager MJ and van Bergen J: Evidence for natural killer cell-mediated protection from metastasis formation in uveal melanoma patients. Invest Ophthalmol Vis Sci 50: 2888-2895, 2009.

43. Okada K, Hirota E, Mizutani Y, Fujioka T, Shuin T, Miki T, Nakamura Y and Katagiri T: Oncogenic role of NALP7 in testicular seminomas. Cancer Sci 95: 949-954, 2004.

44. Ohno S, Kinoshita T, Ohno Y, Minamoto T, Suzuki N, Inoue M and Suda T: Expression of NLRP7 (PYPAF3, NALP7) protein in endometrial cancer tissues. Anticancer Res 28: 2493-2498, 2008.

45. Coma M, Vicente R, Busquets S, Carbó N, Tamkun MM, López-Soriano FJ, Argilés JM and Felipe A: Impaired voltage-gated $\mathrm{K}^{+}$channel expression in brain during experimental cancer cachexia. FEBS Lett 536: 45-50, 2003.

46. Usami S, Motoyama S, Koyota S, Wang J, Hayashi-Shibuya K, Maruyama K, Takahashi N, Saito H, Minamiya Y, Takasawa S, Ogawa $J$ and Sugiyama T: Regenerating gene I regulates interleukin-6 production in squamous esophageal cancer cells Biochem Biophys Res Commun 29: 4-8, 2010.

47. Hayashi K, Motoyama S, Koyota S, Koizumi Y, Wang J, Takasawa S, Itaya-Hironaka A, Sakuramoto-Tsuchida S, Maruyama K, Saito H, Minamiya Y, Ogawa J and Sugiyama T: REG I enhances chemo- and radiosensitivity in squamous cell esophageal cancer cells. Cancer Sci 99: 2491-2495, 2008.

48. Wiśniewski A, Jankowska R, Passowicz-Muszyńska E, Wiśniewska E, Majorczyk E, Nowak I, Frydecka I and Kuśnierczyk P: KIR2DL2/S2 and HLA-C C1C1 genotype is associated with better response to treatment and prolonged survival of patients with non-small cell lung cancer in a Polish Caucasian population. Hum Immunol 73: 927-931, 2012.

49. Almalte Z, Samarani S, Iannello A, Debbeche O, Duval M, InfanteRivard C, Amre DK, Sinnett D and Ahmad A: Novel associations between activating killer-cell immunoglobulin-like receptor genes and childhood leukemia. Blood 118: 1323-1328, 2011.

50. Cumming AP, Hopmans SN, Vukmirović-Popović S and Duivenvoorden WC: PSA affects prostate cancer cell invasion in vitro and induces an osteoblastic phenotype in bone in vivo. Prostate Cancer Prostatic Dis 14: 286-294, 2011.

51. Mattsson JM, Närvänen A, Stenman UH and Koistinen H: Peptides binding to prostate-specific antigen enhances its antiangiogenic activity. Prostate 72: 1588-1594, 2012

52. Saxena P, Trerotola M, Wang T, Li J, Sayeed A, Vanoudenhove J, Adams DS, Fitzgerald TJ, Altieri DC and Languino LR: PSA regulates androgen receptor expression in prostate cancer cells. Prostate 72: 769-776, 2012.

53. O'Mara TA, Nagle CM, Batra J, Kedda MA, Clements JA and Spurdle AB: Kallikrein-related peptidase 3 (KLK3/PSA) single nucleotide polymorphisms and ovarían cancer survival. Twin Res Hum Genet 14: 323-327, 2011.

54. Black MH and Diamandis EP: The diagnostic and prognostic utility of prostate-specific antigen for diseases of the breast. Breast Cancer Res Treat 59: 1-14, 2000

55. Szczepanski MJ, DeLeo AB, Łuczak M, Molinska-Glura M, Misiak J, Szarzynska B, Dworacki G, Zagor M, Rozwadowska N, Kurpisz M, Krzeski A, Kruk-Zagajewska A, Kopec T, Banaszewski J and Whiteside TL: PRAME expression in head and neck cancer correlates with markers of poor prognosis and might help in selecting candidates for retinoid chemoprevention in pre-malignant lesions. Oral Oncol 49: 144-151, 2012.

56. Español AJ and Sales MN: Different muscarinic receptors are involved in the proliferation of murine mammary adenocarcinoma cell lines. Int J Mol Med 13: 311-317, 2004

57. Fiszman GL, Middonno MC, de la Torre E, Farina M, Español AJ and Sales ME: Activation of muscarinic cholinergic receptors induces MCF-7 cells proliferation and angiogenesis by stimulating nitric oxide synthase activity. Cancer Biol Ther 6: 1106-1113, 2007 
58. Español AJ, de la Torre E, Fiszman GL and Sales ME: Role of non-neuronal cholinergic system in breast cancer progression. Life Sci 80: 2281-2285, 2007.

59. Ferretti M, Fabbiano C, Di Bari M, Ponti D, Calogero A and Tata AM: M2 muscarinic receptors inhibit cell proliferation in human glioblastoma cell lines. Life Sci 91: 1134-1137, 2012.

60. Cabadak H, Aydin B and Kan B: Regulation of M2, M3, and M4 muscarinic receptor expression in K562 chronic myelogenous leukemic cells by carbachol. J Recept Signal Transduct Res 31: 26-32, 2011.

61. Keenan J, Joyce H, Aherne S, O'Dea S, Doolan P, Lynch V and Clynes M: Olfactomedin III expression contributes to anoikis-resistance in clonal variants of a human lung squamous carcinoma cell line. Exp Cell Res 318: 593-602, 2012.

62. Miljkovic-Licina M, Hammel P, Garrido-Urbani S, Lee BP, Meguenani M, Chaabane C, Bochaton-Piallat ML and Imhof BA: Targeting olfactomedin-like 3 inhibits tumor growth by impairing angiogenesis and pericyte coverage. Mol Cancer Ther 11: 2588-2599, 2012.

63. Rouget-Quermalet V, Giustiniani J, Marie-Cardine A, Beaud G, Besnard F, Loyaux D, Ferrara P, Leroy K, Shimizu N, Gaulard P, Bensussan A and Schmitt C: Protocadherin 15 (PCDH15): a new secreted isoform and a potential marker for NK/T cell lymphomas. Oncogene 25: 2807-2811, 2006.

64. Adachi K, Toyota M, Sasaki Y, Yamashita T, Ishida S, Ohe-Toyota M, Maruyama R, Hinoda Y, Saito T, Imai K, Kudo R and Tokino T: Identification of SCN3B as a novel p53-inducible proapoptotic gene. Oncogene 23: 7791-7798, 2004

65. Rodrigues RG, Panizo-Santos A, Cashel JA, Krutzsch HC, Merino MJ and Roberts DD: Semenogelins are ectopically expressed in small cell lung carcinoma. Clin Cancer Res 7: $854-860,2001$

66. Zhang Y, Wang Z, Zhang J, Farmer B and Lim SH: Semenogelin I expression in myeloma cells can be upregulated pharmacologically. Leuk Res 32: 1889-1894, 2008.

67. Hienonen T, Sammalkorpi H, Enholm S, Alhopuro P, Barber TD, Lehtonen R, Nupponen NN, Lehtonen H, Salovaara R, Mecklin JP, Järvinen H, Koistinen R, Arango D, Launonen V, Vogelstein B, Karhu A and Aaltonen LA: Mutations in two short noncoding mononucleotide repeats in most microsatelliteunstable colorectal cancers. Cancer Res 65: 4607-4613, 2005.

68. Mitra A, Richardson RT and O'Rand MG: Analysis of recombinant human semenogelin as an inhibitor of human sperm motility. Biol Reprod 82: 489-496, 2010.

69. Canacci AM, Izumi K, Zheng Y, Gordetsky J, Yao JL and Miyamoto H: Expression of semenogelins I and II and its prognostic significance in human prostate cancer. Prostate 71: $1108-1114,2011$.

70. Santagata S, Maire CL, Idbaih A, Geffers L, Correll M, Holton K, Quackenbush J and Ligon KL: CRX is a diagnostic marker of retinal and pineal lineage tumors. PLoS One 4: e7932, 2009.

71. Glubrecht DD, Kim JH, Russell L, Bamforth JS and Godbout R: Differential CRX and OTX2 expression in human retina and retinoblastoma. J Neurochem 111: 250-263, 2009.

72. Terry J, Calicchio ML, Rodriguez-Galindo C and PerezAtayde AR: Immunohistochemical expression of CRX in extracranial malignant small round cell tumors. Am J Surg Pathol 36: 1165-1169, 2012.

73. Yousef GM, Scorilas A, Jung K, Ashworth LK and Diamandis EP: Molecular cloning of the human kallikrein 15 gene (KLK15). J Biol Chem 276: 53-61, 2001.

74. Yousef GM, Scorilas A, Katsaros D, Fracchioli S, Iskander L, Borgono C, Rigault de la Longrais IA, Puopolo M, Massobrio M and Diamandis EP: Prognostic value of the human kallikrein gene 15 expression in ovarian cancer. J Clin Oncol 21: 3119-3126, 2003.
75. Rabien A, Fritzsche FR, Jung M, Tölle A, Diamandis EP, Miller K, Jung K, Kristiansen G and Stephan C: KLK15 is a prognostic marker for progression-free survival in patients with radical prostatectomy. Int J Cancer 127: 2386-2394, 2010.

76. Yousef GM, Scorilas A, Magklara A, Memari N, Ponzone R, Sismondi P, Biglia N, Abd Ellatif M and Diamandis EP: The androgen-regulated gene human kallikrein 15 (KLK15) is an indpendent and favourable prognostic marker for breast cancer. Br J Cancer 87: 1294-1300, 2002.

77. Kudo Y, Ogawa I, Kitajima S, Kitagawa M, Kawai H, Gaffney PM, Miyauchi $\mathrm{M}$ and Takata T: Periotin promotes invasion and anchorage-independent growth in the metastatic process of head and neck cancer. Cancer Res 66: 6928-6935, 2006.

78. Malanchi I, Santamaria-Martínez A, Susanto E, Peng H, Lehr HA, Delaloye JF and Huelsken J: Interactions between cancer stem cells and their niche govern metastatic colonization. Nature 481: 85-89, 2011.

79. Kanno A, Satoh K, Masamune A, Hirota M, Kimura K, Umino J, Hamada S, Satoh A, Egawa S, Motoi F, Unno M and Shimosegawa T: Periostin, secreted from stromal cells, has biphasic effect on cell migration and correlates with the epitelial to mesenchymal transition of human pancreatic cancer cells. Int J Cancer 22: 2707-2718, 2008.

80. Kyutoku M, Taniyama Y, Katsuragi N, Shimizu H, Kunugiza Y, Iekushi K, Koibuchi N, Sanada F, Oshita Y and Morishita R: Role of periostin in cancer progression and metastasis: Inhibition of breast progression and metastasis by anti-periostin antibody in a murine model. Int J Mol Med 28: 181-186, 2011.

81. Carter H, Samayoa J, Hruban RH and Karchin R: Prioritization of driver mutations in pancreatic cancer using cancer-specific high-throughput annotation of somatic mutations (CHASM). Cancer Biol Ther 10: 582-587, 2010.

82. Li Q, Wang L, Tan W, Peng Z, Luo Y, Zhang Y, Zhang G, Na D, Jin P, Shi T, Ma D and Wang L: Identification of ClqTNF-related protein 4 as a potential cytokine that stimulates the STAT3 and $\mathrm{NF}-\mathrm{\kappa B}$ pathways and promotes cell survival in human cancer cells. Cancer Lett 28: 203-214, 2011.

83. Belirgen M, Berrak SG, Ozdag H, Bozkurt SU, EksiogluDemiralp E and Ozek MM: Biologic tumor behavior in pilocytic astrocytomas. Childs Nerv Syst 28: 375-389, 2012.

84. Huang YW, Jansen RA, Fabbri E, Potter D, Liyanarachchi S, Chan MW, Liu JC, Crijns AP, Brown R, Nephew KP, van der Zee AG, Cohn DE, Yan PS, Huang TH and Lin HJ: Identification of candidate epigenetic biomarkers for ovarian cancer detection. Oncol Rep 22: 853-861, 2009.

85. Heller G, Babinsky VN, Ziegler B, Weinzierl M, Noll C, Altenberger C, Müllauer L, Dekan G, Grin Y, Lang G, End-Pfützenreuter A, Steiner I, Zehetmayer S, Döme B, Arns BM, Fong KM, Wright CM, Yang IA, Klepetko W, Posch M, Zielinski CC and Zöchbauer-Müller S: Genome-wide $\mathrm{CpG}$ island methylation analyses in non-small cell lung cancer patients. Carcinogenesis 34: 513-521, 2013.

86. Wirth T, Soeth E, Czubayko F and Juhl H: Inhibition of endogenous carcinoembryonic antigen (CEA) increases the apoptotic rate of colon cancer cells and inhibits metastatic tumor growth. Clin Exp Metastasis 19: 155-160, 2002.

87. Arrieta O, Saavedra-Perez D, Kuri R, Aviles-Salas A, Martinez L, Mendoza-Posada D, Castillo P, Astorga A, Guzman E and de la Garza J: Brain metastasis development and poor survival associated with carcinoembryonic antigen (CEA) level in advanced non-small cell lung cancer: a prospective analysis. BMC Cancer 9: 119-128, 2009.

88. Liebhardt S, Ditsch N, Nieuwland R, Rank A, Jeschke U, Von Koch F, Friese K and Toth B: CEA-, Her2/neu-, BCRPand Hsp27-positive microparticles in breast cancer patients. Anticancer Res 30: 1707-1712, 2010. 